\title{
After All, I Am the Trangpha. Oppositional Strategies in Shina Radio Dialogues from Gilgit ${ }^{1}$
}

\author{
Almuth Degener \\ University of Mainz
}

\begin{abstract}
The following article intends to be a contribution to the study of conflict talk, based on materials in the Shina language from radio dialogues broadcast in the 1980s. Shina is an Indo-Aryan language of the Dardic group. Shina has been studied by linguistically interested scholars since the nineteenth century and more intensively in the twentieth century. ${ }^{2}$ The first attempts to develop it as a literary language were made in the 1960s. Gilgiti Shina, the language used in the radio features, is spoken in the fertile valley of the Gilgit River, with the greatest number of speakers living in the environs of Gilgit town, Northern Pakistan. Gilgit is a major hub for mountaineering expeditions to the Karakoram. Its population is of various ethnic

1 This paper is the annotated version of a lecture held at the Facoltà di Studi Orientali, Università degli Studi di Roma “La Sapienza”, on 12 February 2010.

2 The first serious grammar was published by T. Grahame Bailey: Grammar of the Shina (Sin̄a) Language, London 1924; major contributions were made by G. Buddruss, e.g. "Shina-Rätsel” (in Nānāvidhaikatāa. Festschrift für Hermann Berger, ed. by D. Kapp, Wiesbaden 1996); by Carla F. Radloff, e.g. Folktales in the Shina of Gilgit (with Shakil A. Shakil, Studies in Languages of Northern Pakistan, 2, Islamabad 1998); by Ruth L. Schmidt, e.g. “A grammatical comparison of Shina dialects" (in Himalayan Languages, Past and Present, ed. by Anju Saxena, Berlin/New York 2004); by M. Amin Zia, e.g. Sawéenoo moórye (Islamabad 1978), and others.
\end{abstract}


affiliations, and besides Shina several other languages are spoken, some of them not genetically related to Shina. Most of the inhabitants of Gilgit are Muslim. The stress of the article is on how facethreatening is dealt with in conflict discourse with two participants. In the process it will be shown how discourse strategies familiar from western languages and ancient rhetoric and culturally determined tendencies combine to form a distinctive argumentative style. It is suggested that the character of the radio dialogues is such as to help radio listeners reflect on the role of the people of Gilgit in modern times against the background of their cultural, religious and social heritage.

Keywords: Indo-Aryan, Shina, Gilgit, radio dialogues, conflict discourse, dialogue analysis, argumentation style, impact of radio features, interlinear text analysis.

From 1984 on Radio Gilgit in a weekly programme broadcast one-act plays or radio features in the Shina language. ${ }^{3}$ It was scheduled for 25 minutes, and could be received within a radius of some 10 miles. The name of the programme was Bayáak "The meeting place". The author was Muhammed Amin $\mathrm{Zia}^{4}$ who prepared a script for the speakers, hand-written in Shina, in a modified Urdu script. These manuscripts were only meant to be used during the recording, and were not kept afterwards. Georg Buddruss of the University of Mainz in Germany acquired a collection of seven manuscripts of radio features which were broadcast in 1984-85. He transcribed the Shina text phonologically and checked it word by word with the author. The

3 "Radio Pakistan began broadcasting in Shina from Rawalpindi in 1949 and from Gilgit in 1979.” (Kohistani/Schmidt 2006, 140). The situation at the beginning of the 21st century is described as follows (ibid., 152): "News reports in Shina are broadcast from Islamabad Radio Station. ... Gilgit Radio Station broadcasts folk songs, ghazals, dramas, commentaries, and stories.”

4 M. Amin Zia is the author of several books in Shina and on Shina language, e.g. his collection of proverbs Sawéenoo moórye, Islamabad 1978, his Shina grammar Sinaa qaa'ida aur graaimar, Gilgit 1986. He is a well-known poet in Shina and Urdu, cf. Buddruss 1993a, and Degener 2008. 
features have not yet been published, ${ }^{5}$ but G. Buddruss kindly let me use his transcriptions and spared many hours of his precious time to let me partake of his knowledge and experience.

The radio features are remarkable in more than one way. Shina as a literary language was still (and has continued to be) in the process of being developed. The texts that had until then been written in Shina had a different character: poetry, proverbs, short non-literary texts. It must be seen as a considerable achievement by the author M. Amin Zia to practically introduce a new literary genre of Shina literature. The script is only imperfectly suited for the representation of Shina phonology, ${ }^{6}$ and what is more, no reading routine in the Shina script could be taken for granted. For the speakers it would most probably have been much less painstaking to read out an Urdu text than one in their mother tongue. The features use a highly colloquial style characterized by extensive use of discourse particles and interjections, ${ }^{7}$ the exact function of which is not always clear. Despite being by now historical texts and despite the fact that Bayáak was not

5 They were described in some detail in Buddruss 1993b. It is intended to publish them in the near future so as to make the data available to researchers.

6 If any consistency in the use of the Shina script for the use of manuscripts has been achieved since the '80s, it seems to be restricted to Gilgit, cf. Kohistani/ Schmidt 2006, 153: "The staff of the Islamabad Radio Station ... have little time for improving their knowledge of Shina. They have also failed to adopt a standardized writing system, so manuscripts are produced with no systematic rendering of Shina phonology and vocabulary. At the Gilgit Radio Station, the day-to-day interface with Shina-speaking writers and scholars has led to an improvement in language use, and script writers do try to standardize the spelling of Shina to be consistent with Shina phonology. This represents the beginning of a standardization process, though only in Gilgit."

7 Unfortunately, not having access to taped material, we are unable to evaluate to what extent the script was followed during the recording. According to G. Buddruss, the scripts for news and short announcements in Shina were imprecise and would commonly be amplified by the speaker: "Für kurze Ansagen und für Nachrichten, die von einer Urdu-Agentur übernommen werden, machen sich die Radiosprecher ein Textgerüst in sehr ungenauer Schrift, das sie dann vor dem Mikrophon mehr oder weniger amplifizieren" (Buddruss 1983, 237). As for Bayáak, the meticulous writing down of interjections and particles seems to indicate, that in this case the actual performance was meant to keep to the script more or less exactly. 
a live programme with spontaneous interaction, ${ }^{8}$ the texts therefore provide samples of the language spoken 30 years ago, and to use them as data basis for linguistic studies is intriguing. Furthermore, even this relatively small text corpus testifies to the way how people with a particular cultural background use language and rhetoric creatively in a particular communicative situation. It is so far the only available text corpus in Shina which - being colloquial dialogue rather than narrative - lends itself to discourse analysis. Finally, the features are interesting because they reflect Gilgit society in the 1980s with its particular problems and concerns.

There are two main characters who appear in every program, Taaj, a young man, and the village elder, in Shina called the trayphá. The dialogue takes place on the village common, the usual place for everybody to meet and talk. This place is called bayáak in Shina, and this is also the name of the programme. The trangpha is the representative of the conservative older generation. He appears as oldfashioned and reluctant to participate in development, but the radio features are complex enough not to make him an unsympathetic character. Taaj stands for the better-educated, modern, but sometimes naive and careless young generation. The radio features consist of discussions between the opponent parties. There is a third character, Maashtar Sahab, the schoolteacher. As a man whose learnedness and status predestine him for a position above party politics, he is respected by all the participants. The Maashtar Sahab is beyond reproach in all respects. His arguing is always matter-of-fact, he never gets carried away by emotions; he always tries to mediate between the extremes and to prevent aggravation of the conflict. As the purpose of this study is the analysis of a particular aspect of conflict talk, i.e. the reaction to face-threatening acts, and the teacher hardly ever is the target of a verbal attack, he may be disregarded here. interaction. Paradoxically, however, the dialogue in drama or fiction often strikes audiences as extremely realistic ... If audiences respond favorably to the contrived dialogue of literary productions, then such dialogue represents something that rings true to them. ... [Analysis of literary dialogue is analysis] of a type of representation of human interaction that has at least symbolic significance for members of the culture that appreciate the artistic production." (Deborah Tannen in Grimshaw 1990, 261). 
The discussions focus on problems of everyday life, on current controversies and tensions in the community of Gilgit. Their popularity can hardly be overexaggerated. To illustrate the reception they met with, it will be enough to repeat an anecdote told by G. Buddruss (1993b, 48): "In one of his plays Amin Zia had slightly ridiculed the shortcomings of the refuse disposal in Gilgit. This was taken ill by some Gilgit dustmen, who vowed revenge. Two days later, Amin found a huge stinking rubbish heap in his courtyard piled up there at daybreak by his angry listeners."

A first look at one of the dialogues ${ }^{9}$ will give a general impression of the nature of the conflict talk implied. In the immediately preceding passage at the beginning of one of the radio features the trangpha greets Taaj, calling him "orphan duckling”, literally "a duckling which has been isolated from the flock". This address is little short of an insult in Gilgit, where a person's status is for a major part determined by his family links and the family's standing in the community. ${ }^{10}$ To be without a family with local roots means to be an outsider, to be weak and untrustworthy. When Taaj complains of the inappropriate expression, the trangpha teases him:

Trangpha:

nu jéek galát mórak thigás, laá Táaj, mas? thar bíli baruṣóyak thoóiky ginií tu judá róoṣ bigáa náa?

"What wrong word have I said? It seems you are angry about my calling you 'orphan duckling'”?

This question could be answered straightforwardly by "Yes," possibly followed by an argument "because you have insinuated that I am without a respectable family.” But that is not what Taaj does, and in fact both participants hardly ever give a straightforward yes-or-no answer. Taaj gives three answers:

9 An interlinear analysis of the dialogues quoted is given in the appendix.

10 Cf. proverbs Nos. 1-12 and 127-134 in Degener 2008. 
Taaj:

1) na yá tranpháa, róoṣ boóikyei mor nuš,

"No, trangpha, this is not a word to be angry about."

2) née róoṣ beé ga mas jéek thoóiky bámus tut? atáto saá rpuk hanó, "náwaary-ráwaary tham" thigás toó, thei aní tótoo ek șa wét tak hanús. ek to phat tharoóiky ga koó nuš.

"On the other hand, even if I was angry, what could I do to you? You are such a powerful guy; if I want to discuss with you, I'll get a slap round the face from your paws. There is no one to stop (you).”

3) tu jée Gulam Díin hanó to, jéek reégas to ga "waá mei šutúko, adée neé ra née!" theé čup thée.

"You are not Gulam Din, are you, to say calmly 'Well, my darling, don’t speak thus,' if I say anything!” (Dialogue 1.1-2)

First he qualifies the trangpha's statement, thereby denying that it is an insult. Then he criticizes the trangpha as being tyrannical. He does this indirectly, by adducing his own powerlessness and by means of a counterexample, namely Gulam Din who is an old and respected man like the trangpha, but apparently more obliging. The question is not one of being true or untrue. The dialogues make it perfectly clear that Taaj is by no means helpless or intimidated, neither is there a hint of the trangpha's ever using physical or political violence against him. It is rather a strategy of expressing disagreement in accordance with the social conventions. The indirect approach allows the discussion to go on with both parties keeping their face despite controversary opinions.

Conflict talk deals with one aspect of discourse which has found much attention in communication and linguistic sciences for about thirty years. Depending on the perspective of the researcher and on the nature of the data, various aspects of conflict and conflict talk have 
been studied. ${ }^{11}$ The present paper deals with radio dialogues in a littleknown language which were broadcast in Pakistan over 20 years ago. Its aim is to better understand the texts rather than to contribute to a particular theory. Literature on conflict discourse has accordingly been used with no consideration for school affiliation and to the extent that it has helped to further this aim. Among the works I have found particularly inspiring are the following: the survey articles of C. Kakavá (2001) and of Linda L. Putnam (in Oetzel and Ting-Toomey 2006, 1-32), J. M. Conley and W. M. O’Barr's article on legal dispute in "Rules versus relationships in small claims disputes" (in Grimshaw 1990, 178-196), W. A. Corsaro and T. A. Rizzo's study on "Disputes in the peer culture of American and Italian nursery-school children" (in Grimshaw 1990, 21-66), M. Hartung's thesis (1998) on all aspects of irony, the classification of representation vs. quasilogic and analogy by B. Johnstone (1989), and last, but not least M. Billig's (1989) delightful analyses of strong views expressed at British family tables.

A conflict will be defined here as a situation in the conversation where opposite interests or values are explicitly expressed. ${ }^{12}$ The conflict process always and inevitably implies face-threatening acts, ${ }^{13}$ and often involves emotional engagement. For the sake of convenience, each conflict will be described as a minimal action

11 See Leung 2002 and the preliminary remarks in Kakavá 2001.

12 Persuasion and argumentation are part of conflict communication, but not synonymous with conflict itself, cf. Linda L. Putnam, in: Oetzel/Ting-Toomey, 8.

13 Face is a central concept of sociolinguistics and related fields which goes back to an early article by Erving Goffman ("On Face-Work: An Analysis of Ritual Elements in Social Interaction,” Psychiatry: Journal of Interpersonal Relations 18:3 (1955), pp. 213-231, reprinted in: Interaction Ritual, pp. 5-46. In the German edition Interaktionsrituale, Frankfurt 1971, "face" is translated by "Image", but "face" is commonly used as a technical term in German and other non-English languages.). Goffman's basically dramaturgical perspective suggested that people in social interaction assume variable roles and masks which in turn provide both self-esteem and approval by fellow actors. Face is the positive social value a person claims for himself and expects others to respect. It can be threatened, lost, maintained, or enhanced. The efforts taken to maintain or enhance face in interaction and to save face in a threatening communicative situation are called facework. Face-saving strategies are known in all cultures, but are particularly important in a cultural context like in Pakistan where personal and social esteem is essential to all social interaction. 
game ${ }^{14}$ consisting of a face-threatening act and its response. The scope of this paper is confined to analysis of the response part, i.e. of the strategies used by the participants with the intention to voice opposition, to avoid loss of face and to push their own view. ${ }^{15}$

1. Oppositional strategies of Taaj

1.1 Censure of the utterance as inappropriate

When the trangpha accuses Gulam Din of bribing, this is a severe provocation for Taaj, who has previously praised Gulam Din as his friend:

Trangpha:

Gulám Díinei moóryes diš lamoóiky çaké, rései lik doóiky paáš! toóm mataláb nikhaloóikyet jagoóo máal-háal húuṣi doóikyei kom toó Gulám Díin-se mísțtuk theé dišét waléen.

"Look, how well Gulam Din's words are received, see how he offers bribes! In order to pursue his own interests, he performs very well the work to loot other people."

Taaj must counter the provocation to save his face, but knowing that the trangpha's statement is true, an explicit denial is impossible. Instead he chooses an evasive strategy:

14 Edda Weigand, in Weigand 2004, 11: “Action can be initiative or reactive. The basic minimal structure of the action game is constituted by the sequence of action and reaction which can be extended by sequencing principles of negotiation. The expected reaction is functionally and rationally determined by the initiative action."

15 The terms 'view' and 'attitude' will be used in a non-technical sense. 
Taaj:

mor koó ga béen náa, oó mukhá thoóiky yupóoš béen. aš Gulám Díin ga maaștár sáap nuš theé rinéi píte phatú rinót čóde deégyes to, anú mor místuk béy-aa?

"If you have anything to say, then you should say it face to face. Will it be good to speak about Gulam Din and the Maashtar Sahab behind their back today, when they are not present?” (Dialogues 3.2 and 5)

Taaj's rejection is not directed at what the trangpha said, but at his way of saying it, or at the fact that he says it at a particular occasion. Irrespective of whether it is true or not, the utterance is inappropriate. As such it has to be disregarded and is therefore unpersuasive. At the same time the speaker acts as a judge of the opponent's moral standards, and as he refers to common values, ${ }^{16}$ he is unassailable. The trangpha's answer "What you say, is correct, but ..." confirms that Taaj's strategy has - even if the trangpha won't give up his position been successful, i.e. Taaj's face has been saved.

\subsection{Censure of the opponent}

As a typical representative of the older generation, the trangpha finds it difficult to accept the lifestyle of young people who grow up under changed economic and political conditions. To him, young people seem to be indolent, sybaritic, and irresponsible.

Trangpha:

aní aš-balá zamaanáai ayaašiíyo phatú gárak čáakak šudáaryes téen hamarí ga toonóo deé gúum makéi bazáarer lam thareégye-t, khyée theé bes híiyo šóo thóon ...ninójo?

"How shall we have a liking for young people, when some of them, given to the luxuries of modern times, break up corn containers and sell the (stolen) wheat and maize in the bazaar?” 
Taaj:

awá náa, toóm hotaléi našá phatuú thoóikyet toó tus jéek ga neé théeno? tom-talúu, šúko meewá ga laç-čhaál chos hotaléi šáawo mazá uḍoór thóoja ç chawáa tonée asót kanaáo tháa to bes kon deé beétes?

"Yes, and to pursue your own hotel pleasures you don't do anything, do you? When you give us your advice while you yourself waste trees and shrubs, dry fruit, sheep and goats for the taste of hotel curries, shall we listen quietly?” (Dialogue 8.1-2)

The trangpha accuses young people of wasting precious goods to amuse themselves. Taaj points out that the trangpha and his friends waste much more for their own pleasures. However, Taaj does not confine himself to returning the accusation. He adds another point which acts to invalidate the original critique. According to Taaj, wasting goods is reprehensible, but much worse is the fact that just those people who practice it, set out to give advice to others. In this way, he disputes the trangpha's adequacy as a judge of others' behaviour.

\subsection{Irony}

According to the trangpha his age and social status oblige Taaj to treat him respectfully and tolerate an occasional rebuke:

Trangpha:

má-saa ty beéto to, miștuk beé asíl auláadakei, zaáakei širií beyií mor the! aaxír ma trayphá hanús...

"When you are with me, sit down properly and talk like a wellbehaved child or a brother! After all I am the trangpha..."

The answer Taaj gives, may out of context look like praise, but is clearly the opposite: 
Taaj:

heyíi hei! ye insáan boóiky heesiyát ginií ga jagó majaá ga kačáak phárak haiñ caké-t!

"Hey, look, what big differences there are among people despite their common ground of being human!” (Dialogue 1.3-4)

Taaj seemingly marvels at the trangpha's wisdom, like the wellbehaved child he has been asked to be. In fact, however, and plainly enough for the trangpha, he accuses him of violating one of the principles of Islam. In his ironical answer Taaj refers to the Islamic doctrine that all men are equal before God. ${ }^{17}$ If the trangpha insists on his higher status, the unacceptable consequence would be that he claims for himself a superiority not sanctioned by Islam.

In the next example the reply plays on the intentional misinterpretation of a word, and in this misinterpretation lies the humorous potential for the radio listener. The opposition strategy used, however, is again irony.

Trangpha:

ye çaké née! ḍaalḍáai jawáanoo máto! jáale-jo çíto giíyak las neé thíte čáakuroo pháam akíi kam haiñ ya!

"Just look! The brains of Daaldaa ${ }^{18}$ youngsters! Even the intelligence of young people who haven't tasted bitter ghee in their early childhood, is small."

17 In this context usually Quran 49, 13 is quoted as well as a famous saying ascribed to the prophet: "People are as equal as the teeth of a comb, they are differentiated only by piety."

18 daaldaa is the name of a vegetable oil which would not have been sold when the trangpha was a child. 
Taaj:

awá, cho çíto giyéi lagáare jak bóde bạre sawéene yáani Aflatúuni ga Sakaráati hanét hoó. gií ga pajúu kámak baáski kháa to, ho blaḍ-préšer beé lanijoóiky hanét.

"Yes, you adherents of bitter ghee are true Platos and Socrateses. Just eat a little more more ghee and salt, then you'll die of (high) blood pressure.” (Dialogue 4.1-2)

The trangpha claims that young people lack understanding, because they haven't had to put up with hardships in their youth as has his own generation. Taaj deliberately misunderstands the metaphorical "bitter ghee” as ghee ${ }^{19}$ in the literal sense. He applies it to the hotel ${ }^{20}$ going habits of the trangpha, which will not result in higher intelligence, but in ruined health. The ironical strategy Taaj chooses is, however, in this case lost on the trangpha who does not understand any of the words "Plato", "Socrates" and "blood pressure" which belong to the vocabulary of higher education.

2. Oppositional strategies of the trangpha

2.1 Valuation of the speaker

In the dialogue quoted initially Taaj claims that the trangpha would react violently if Taaj attempted to discuss with him:

Taaj:

née róos beé ga mas jéek thoóiky bámus tut? atáto saá rpuk hanó, "náwaary-ráwaary tham" thigás toó, thei aní tótoo ek șa wét tak hanús; ek to phat tharoóiky ga koó nuš. tu jée Gulam Diin hanó to, jéek reégas to ga "waá mei šutúko, adée neé ra née!" theé čup thée.

19 Clarified liquid butter used in cooking all over the Indian subcontinent.

20 'Hotel' (Shina hótal) is the ambitious term the trangpha uses for a very modest kind of restaurant or rather stall where a soup or a curry would be served to local customers for a low price. 
"Even if I was angry, what could I do to you? You are such a powerful guy: if I want to discuss with you, I'll get a slap round the face from your paws. There is nobody to stop you. You are not Gulam Din, are you, to say calmly: 'Well, my darling, don’t speak thus!'”

This utterance is face-threatening, because the trangpha considers himself to be an important man who has to be respected, but he does not want to be seen as tyrannous. His reply will accordingly stress that there is no question of bullying on his part, but that respect is due for other, more honourable reasons. As usual, there is no explicit denial of authoritarian behaviour. Instead, the trangpha's response focusses on the social hierarchy:

Trangpha:

ye phat the, laá záa! tus to Gulám Díineǰ achíi seéguno. másaa ty beéto to, miștuk beé asíl auláadakei, záakei širií beyií mor the! aaxír ma trayphá hanús. ma jéek Gulám Díin neé toó thei isiháa moórye timaní tham.

"Leave that, brother! On Gulam Din you have influence. (But) when you are with me, sit down properly and speak like a wellbred child or a brother! After all I am the trangpha! I am hardly Gulam Din to tolerate your mockery.” (Dialogue 1.2-3)

As he has been cited as a counterexample for the trangpha's overbearing attitude, Gulam Din is dismissed: if he is influenced by Taaj, there is no point in naming him as an independent witness. Then the trangpha insists that he occupies the position of the trangpha and as such has a right to respectful behaviour in his presence. The discrediting of the opponent's argument goes along with an appraisal of the speaker's rank which is so much higher in the hierarchy that critique appears as impudence. Again there is no question of truth or untruth: apart from age and experience the trangpha can hardly claim a prominent or high position for himself. Subjectively, however, his respectability is a very important aspect for the trangpha, as is also apparent from two more passages where he says much the same: 
Taaj:

thei ne to hotaléi júuli ga julaabíiye khoóikyei açuúunuk haiñ áa i, moórye thoóiky áa i toó mei Gulám Díin zawéi haiñ.

"Your mouth here is a hole to swallow curries and biscuits from the hotel - a mouth to speak, that is the one of my brother Gulam Din.”

Here again, the trangpha is compared with Gulam Din, and the reply is a variant of what he has stated before:

Trangpha:

aaxir ma jéek kam mušáak nuš. raǰó maraká bóot yáa kuléi, sarkaarí afsaró muçhoó, adaalató majaá mukh nikháto mušáa anú han, anú tranphá. mor páčen toó har dišér anú mušáai. mukh loólyo han toó, har dišér anú mušáai. parúdoo?

“... After all, I am not some lowly man. In meetings of kings and of the people, in front of government officials, in law courts, - the man, whose face is prominent is this one, this trangpha. The man whose word counts everywhere, it is this man (myself). When somebody's face is red (i.e. when he is successful and respected), it is the face of this man everywhere. Have you understood this?” (Dialogue 2.1-2)

The trangpha tries to make his claim - that he is an important man of the public - maximally present in the hearer's consciousness, by repeating and paraphrasing it over and over again. The following example is taken from near the end of a radio feature, after some degree of consensus has been reached. Taaj doubts that the trangpha's verbal support for improvement of public morale will imply that he also takes responsibility for implementing it: 
Taaj:

aáiñ "šóo šóo" theé gyeé née toóm dišér daníi toómi akíi dée. urinéi širií dáar maraák beé amušoóiky toó thei aadát haiñ.

“... Here you say 'well, well', and then you go back to your old ways and do what you want. You are used to forget, like the mountain sheep after it has turned its back on the mountain.”

Taaj refers to a proverb ${ }^{21}$ which is variously applied to ingratitude or to suppression of memory after the danger is past. Again, the trangpha reacts with emphasis on his own standing.

Trangpha:

neé ya, Táaj! ma aaxér próono mušáa hanús. raǰi wazíiri ga sarkaarí afsáro sáa ty khíto píto insáanak hanús. aaxér ayáakak saadá tus ma ga neé kalí née!

"No, no, Taaj! After all, I am an old ${ }^{22}$ man. I am a man who has sat at the same table as kings, ministers and government officials. At last don't take me to be such a simpleton!" (Dialogue 7.1-2)

\subsection{Censure of the participant}

Censure of the opposing party is the other side to appraisal of oneself. In both cases the tactics try to invalidate the opponent's argument by pointing to its inappropriateness in view of the participant's person.

Taaj:

ye bas, "xuškhatíi kúri thámus" theé, née Gulám Díinei mor wáan, "mukhéj dul-khalúc ginií xuškhatíi bósak theé laár be hótal hótal júulyer pajúu çakóoja yaáyeno."

21 No. 255 in Degener 2008.

22 'Old' of course has to be understood in the sense of 'venerable, respectable'. 
“Enough! 'Intending to excel in calligraphy', to quote Gulam Din, you apply lots of calligraphy with make-up on your face and go swaggering from hotel to hotel to look at the salt in the curry."

Taaj makes mockery of the trangpha's lack of education. In the schools of the old days ${ }^{23}$ little more was taught beside calligraphy, and even that, Taaj claims, the trangpha does not know. According to Taaj, all his energy is spent on outward appearances and the pleasures of eating and drinking. The trangpha replies with a question:

Trangpha:

Táaj, tut aaxír aséi bazáarer kiirr-kaár boóiky ga kye kháči dîjin? maphéeri jée bathunáryej tráa theé ganeé cho čáakurnásal-se maroóiky guneégyenet bei?

"Why don't you like us to stroll around the bazaar? Did you, the younger generation, want to tie us to the hearth stone and kill us?” (Dialogue 5.1-2)

Accused of ignorance and gluttony, the trangpha imputes evil intentions to Taaj. He uses the plural form of the personal pronoun 'our (strolling around the bazaar)' to divert the attention from his own person and make Taaj's attack look as if it was directed at the older generation in general (Taaj may indeed have meant this, but he uses the $2^{\text {nd }}$ person singular). The accusation is, he claims, just a pretext for young people who want to ban the older generation completely from their lives. In that way the young man - and in the process the younger generation - is discredited, for if they really are prejudiced against old people, they are not qualified to judge the lifestyle of the older generation.

23 The trangpha in another dialogue claims for himself participation in the revolt which broke out in 1947. So his childhood would have been in the time when Gilgit belonged to the princely state of Jammu and Kashmir, while the political power often had to be ceded to the British government of India as suzerain power of Kashmir. 
In the next example Taaj accuses the trangpha of bribery. He expresses it as a general, aphoristic statement, but his message is clear:

Taaj:

har dišér oó manúzei mór-se diš laámen tonée eései kom nikháan, koós munaafiqát thoóiky suí yen, lik doóiky tíyen, jaaíz ga naajaaíz tariká ginií toóm hațáal kom nikhaloóikyet áar das neé théen.

“Everywhere that man's word will be heard and that man's work is successful, who knows how to use hypocrisy, who can give bribes, who is not ashamed to use every legal and illegal means to get his way, if his work is not coming along well.”

In response, the trangpha points out that bribery is just what Taaj's friend Gulam Din regularly practices.

Trangpha:

heee , mor kóto thigáa. Gulám Díinei moóryes diš lamoóiky çaké, rései lik doóiky paáš! toóm mataláb nikhaloóikyet jagóo máal-háal húuși doóikyei kom toó Gulám Díin-se misștuk theé dišét waléen. ros akii ráan ki "bes jagóojo karkaámuše ga hanejé sinaleé tran oó še-apháarot dóoneses tonée trạ toóm gotét hároneses" theé.

“There you have said something! Look, how well Gulam Din’s words are received, see, how he offers bribes! In order to pursue his own interests, he performs very well the work to loot other people. He himself says: 'Having collected chickens and eggs from the people, we give half of it to guests, and carry half of it into our own house."” (Dialogue 3.1-2)

The trangpha returns the accusation. He keeps his face, for if the accusation is justly made, it applies to both parties, and the other participant loses any right to assert the position of an independent judge. In this way the critique is neutralized. Furthermore, the 
trangpha quotes Gulam Din with a statement which confirms his practising bribery, thus supplying the proof himself and forestalling possible protest. This strategy allows the speaker to divert attention from himself and shift the responsibility for inappropriate behaviour to the other party.

\subsection{Reinterpretation of contents}

In the preceding examples the ever-absent Gulam Din appeared as a favourite of Taaj. However, in order to support their arguments, the contending parties do not hesitate to shift alliances. In the following example Gulam Din is presented by Taaj as a representative of the traditional way to tackle problems.

Taaj:

Gulám Diin lambardáar-se aš toóm brakér karkaámušek deé toóm hatáal kómak nikhaloóikyet gou. parúč! chos adée tháanet.

“... Today the lambardar ${ }^{24}$ Gulam Din went out carrying a chicken in his cloak to push his business which was not coming along well. Listen! That is how you do it.”

Taaj starts telling a recent incident. Mention of time ("today") and personal name (Gulam Din) help to achieve intensified personal involvement, but on the whole it is a simple, emotionally little accented statement. The use of the imperative "Listen!" after the statement signals and calls attention to the explicit disagreement utterance which follows. This is a personal verbal attack and it is emphasised through the use of the plural personal pronoun "you". "You" is meant and understood as "the older generation" which is accused of taking and giving bribes. In his answer the trangpha accordingly takes the role of an advocate for the habits of his generation: 
Trangpha:

ye behél bo! pašiíga be čal zamaanáai mukh nikháte jagóo místi aadát? bes toóm yáar-báar ga daftaróo sijón-pašón jagót daróm daalíyek thoóikyei kom neé nayeégyenes.

"Bravo! Have you seen what is the custom with us, the leaders of the old days? We have not given up giving presents to our friends and people we know in the offices.” (Dialogue 5.3-4)

The trangpha deliberately misunderstands and re-interprets Taaj's reproach as praise. In this way he invalidates the implied facethreatening, because praise cannot possibly have a face-threatening effect. His strategy brands the opponent's argument as being rhetorically unsuccessful, for the trangpha accepts what Taaj said, but not in the intended sense. Taaj reacts with a clarification: daali jéekei? lik doóiky the, lik doóiky! "Present of what? Say: bribe, bribe!" (5.5). This is again a challenge, but implicitly also the acknowledgement that his previous utterance has missed its target, which was to convince the other party of the rightfulness of his accusation.

The trangpha's response in dialogue 3.2 quoted above in section 2.2 might also be interpreted to belong to this category, but the negative connotation of the expression húuși doóiky "to loot" points to another direction.

Even from these few examples certain tendencies will be apparent which as a whole form a particular argumentative style.

\section{Presentation}

The linguist Barbara Johnstone ${ }^{25}$ has categorized persuasive strategies as quasi-logical, presentational, or analogous. In this sense, both participants of the Shina radio dialogues prefer presentational reasoning. Their strategy is not to adduce logical-sounding arguments which start with words like "because" or "consequently". Instead, they try to make the other participant literally "see" the truth by moving and involving him. This is also indicated by the use of the 
corresponding imperatives “see!”, “look!” used by both Taaj and the trangpha. The syntax of presentation is characterized by parataxis. Quite often an argument will be repeated with slight variations, e.g. (a) a statement "you should say it face to face", and (b) a rhetorical question "will it be good to speak about Gulam Din behind his back?" and in the self-appraisal of the trangpha: (a) I am not some lowly man, (b) I appear in meetings of kings etc., (c) my word is listened to everywhere, (d) I am "red-faced" (honorable, famous, successful). Repetition ensures that a certain idea is familiar to the hearer. The aim is to make the hearer feel that this idea is already established and therefore worthy of confidence. After such an enumeration of several times much the same idea the trangpha asks: "Have you understood this?” (Dialogue 2.2, quoted above). Understanding here does not mean intellectual grasping, for there has not been a single logical argument. Understanding means being overwhelmed and convinced by a performance, as in a theatre or film. That the presentational strategy is an accepted mode of arguing and indeed leads to this kind of understanding, is borne out by Taaj's reaction, who (despite continuing dissent) answers: parúdus, parúdus "I have understood, I have understood.”

\section{Reference to authority}

People tend to accept beliefs and opinions from what they see as authoritative, trustworthy, or credible sources. In the Shina radio features, reference to authority is an important element, and this applies to both personal and institutional authority. By personal authority I mean the authority of a person, by institutional authority I mean in this context religion and tradition. In response to a challenge by Taaj, the trangpha several times insists on his high status and on his widely acknowledged authority, e. g. aaxír ma trapphá hanús "After all I am the trangpha." Perhaps it is no mere coincidence that in all three examples quoted the challenge is directed at the trangpha's own person, not at his views or at the older generation in general. He is accused of obstinacy, lacking willingness to change and intentional forgetfulness: "here you say well, well, and then you ... do what you want" (Dialogue 7.1), he is accused of tyranny: "if I want to discuss 
with you, I'll get a slap from your paws” (Dialogue 1.2), he is accused of gluttony "your mouth is a hole to swallow curries" (Dialogue 2.1). This seems to indicate that insistence on the speaker's own authority is the chosen answer, if the challenge is a personal attack. Among the characters of the radio features, this strategy is open only to the trangpha, because Taaj, being much younger, cannot claim the social standing essential for this approach.

When Taaj and the trangpha refer to institutional authority, they both take it for granted that the other participant associates the same values as they themselves with what they adduce as evidence for their claims. The undisputable authority they both draw upon to support their opposing positions is the religion of Islam. ${ }^{26}$ In fact, both would undoubtedly claim to be good Muslims, but their understanding of it is quite different.

The Islam which Taaj uses to reinforce his arguments, is the institutionalized religion of Quranic teaching. It is this background which provides the basis for his judgment of right or wrong attitudes of the trangpha, e. g. when he points out that the trangpha's claims are contrary to the Islamic equality of all men: "Hey, look, what big differences there are among people despite their common ground of being human!" and when he censures talking behind people's backs: "If you have anything to say, then you should say it face to face." Taaj is not an Islamic scholar and probably doesn't understand Arabic, but he has profited from some religious education, in fact in accordance with contemporary Pakistani policy under president Zia ul-Haq (1978-88) who had taken up the cause of what Zia understood as true Islam, i. e. the Wahhabi version of Pakistani Islam. In another passage Taaj says:

"That is, you, trangpha, have jumped straight into the fire of hell,"

26 The majority of the Gilgit population has been Muslim for several hundred years, cf. Holzwarth, 1998 and 2008. There is a Shia majority amongst Shina speakers, but Sunni Islam has considerable influence in Gilgit and has been encouraged by the former military government of General Zia ul-Haq. A third Muslim religious group are the Ismailis, most of them originally from Hunza. 
and the teacher who has meanwhile joined the party, quotes an Arabic verse from the Quran to confirm this (Dialogues 6.1 and 3).

The trangpha would of course never question the absolute validity of the Quran. But in fact he, who has had little formal education, follows an Islam which finds its expression in time-honoured traditions. He is proud to uphold the principles of olden times: "Have you seen, what is the custom with us...? We have not given up ...” The trangpha's approach to religious issues is pragmatical rather than fundamental. He is very much afraid of the fire of hell (6.2), but he attempts to bargain, qualifying the amount of bribes necessary to qualify for damnation:

"A true word, a true word it is (meaning the quotation from the Quran). But won't it be necessary to take quite a lot of bribes to go to hell?” (Dialogue 6.4)

Whereas Taaj claims that even the intention is enough to make one go to hell, the trangpha treats the threat of damnation like a fine the amount of which is a matter for negotiation. Even if the participants are not conscious of the difference between their beliefs, the trangpha's religion is far from the scripture-oriented, normative Islam followed by Taaj and even more so by the teacher. It is a popular version of Islam which takes account of local needs and customs, and is widespread in Pakistan, where Islam is in a continuing historical process of creative integration between local traditions and the universal message of a world religion.

\section{Personalization}

The negotiating style of Taaj and the trangpha -not that of the school teacher - is highly emotional. Success in a verbal conflict is likely to accrue to the participant who succeeds in deeply involving his opponent on an emotional level. One of the strategies to enhance emotional involvement is personalization of arguments. For example, when Taaj points out that success of the older generation is often due to corruption, the trangpha replies with an ad hominem argument: “Look, how well Gulam Din's words are received, look, how he offers 
bribes!” The strategy is successful, for indeed Taaj immediately protests:

"I am not prepared to accept your word, I am not at all prepared to hear a single word against Gulam Din.” (Dialogue 3.3)

Another strategy is the tu quoque argument, which may not strictly speaking be a variety of personalization, but works in the same way. So when the trangpha accuses young people of plundering, Taaj counter-attacks: "And you don't do anything to pursue your hotel pleasures?...” Even if no names or personal pronouns are used, as in "Look, what big differences there are among people ..." (1.4), this is only seemingly a depersonalization, because it is an ironical remark which is aimed directly at the trangpha's person. It would be wrong to accuse the protagonists of the radio feature of lacking ability to argue in a factual, rational and abstract way. Their arguing is perfectly suited for a style of conflict management which puts emphasis on status and relationships rather than on facts and rules. If arguments will be supported not only because they are reasonable but because they are forwarded by a respected, trustworthy person, then the direct way to be rhetorically successful will be to make one's own person appear superior in this sense while denying the opponent the qualities associated with authority. And if success is ensured by gaining control over the participant's emotions, there could be no better way than to use highly personalized argumentative strategies.

\section{Discrediting}

In the radio-features under examination, there are basically two methods of participants to promote their own claim by putting down the opponent. One, chiefly practised by the trangpha, is to discredit the other participant's argument. This he does, e.g. by claiming that his opponent is biased towards a particular person, as in "On Gulam Din you have influence" (1.3), or he suggests that his arguments are motivated by evil intentions against the speaker, as in "Why don't you like us to stroll around the bazaar? Did you, the younger generation, want to tie us to the hearth stone and kill us?" (5.2). In this way the other participant's judgment is called into question. Furthermore, the 
trangpha's challenges usually have a strong moral taste to them, they put the moral integrity of the other participant into doubt. The discrediting renders the other's utterance rhetorically unpersuasive: a view proposed by someone who is incapable of judgment, is illegitimate and does not have to be taken seriously. Any possible face-threatening is consequently invalidated.

\section{Irony}

The other method of challenging the opponent in order to weaken his argument is the use of irony. ${ }^{27}$ This is the variety practised by Taaj. Gaining control on an emotional level is fundamental to this strategy. It allows the speaker to pass a judgment without explicitly taking up a well-defined standpoint of his own. It aims at showing the opponent's statement or behaviour to be incompatible with consensus, i.e. with standards which may be assumed to be accepted by both parties. If the trangpha, as Taaj insinuates when he says "Look, what big differences there are..." thinks that some men are more worth than others, this will be contrary to the teaching of Islam to which they both adhere. When Taaj says, "yes, you adherents of bitter ghee are true Platos and Socrateses," he presupposes that the Greek philosophers are generally accepted to be unrivalled models of wisdom, so that mentioning them will expose the trangpha as ignorant (unfortunately, this commonplace knowledge is not shared by the other participant). Irony is likely to be used by persons who believe themselves to be intellectually superior, but are inferior in social or physical terms. This suits very well the character who practices it in the radio features, i.e. Taaj, who has had a better school education than the trangpha, but as a young man is lower in the social hierarchy.

Both irony and the claim that the opponent is incompetent of judgment are extremely face-threatening. They lead away from the original argument in favour of preoccupation with the participant's person and character. 


\section{Mitigation?}

This last point has to be labelled with a question-mark.

Hedging, i.e. rhetorically mitigating the impact of one's argument, is not a dominant characteristic of the radio dialogues. After all, the idea of the programme is to mark out the characters' differing positions, not to demonstrate politeness. Even an affirmatory qualification of the "Yes, but ..." type is used to insist on one's own view rather than to cushion disagreement, as will be seen from the trangpha's reaction to the religious evidence adduced by Taaj and the teacher. The quotation from the holy Quran is so strong an argument that it can hardly be contradicted. But when the trangpha says: "A true word, it is (the quotation from the Quran). But won't it be necessary to take quite a lot of bribes to go to hell?” he signals that despite his acceptance of the Quranic verdict, his own conviction, that bribery is not wholly to be condemned, remains intact. So he shows that the other party's argument is correct but argumentatively beside the point, it has not succeeded in deflecting him from his view. The only apparent trace of affiliatory rhetoric is the frequent use of the address as "brother" used by all participants. "Brother", of course, does not refer to any kind of kinship, but is a common informal address for men, so its use should not be overrated. Another possible instance of conciliatory language may be the particle laá as there are some indications that its use suggests an informal, casual relationship of the participants.

There is a great variety of strategies available to both Taaj and the trangpha. Not surprisingly, there is no means to predict a particular communicative strategy in a given conflict situation, but there are preferences to adopt one strategy rather than another, depending on the speaker's indivual qualities, on his perception of the interpersonal constellation, and also on culturally ${ }^{28}$ determined conventions.

28 It may be worthwhile to investigate how Islamic and pre-Islamic local values influence conflict management among the Shina population. Whereas Islamic principles are, among others, the responsibility of the individual for making an effort toward salvation, the equality of men, and the pan-Islamic community of believers ('ummah), major traditional values in Shina Gilgit are, e.g., family (in the widest possible sense) membership, social hierarchy, and the strict 
Conflicts in Bayáak occur relating to matters of behaviour and lifestyle, of authority, and of resources. For a considerable part they are due to changing values and interests amongst the younger generation. However, it would be too narrow to interpret the programme merely as the staging of generational conflicts. This approach fails to recognize that at the root of Taaj and the trangpha's opposing views lies a struggle over identities, ${ }^{29}$ the attempt to define the role of Gilgit inhabitants in the modern age. To take account of the role of identity in conflict communication is essential for understanding its significance in the social discourse of the time. Gilgit society in the '80s was far from being an integrated whole. If individual identity is expressed in terms of ethnicity, regional background, language and religion as well as descent and qaum, ${ }^{30}$ possible concepts for the forming of a communal identity would be language, religion, and the affiliation with Pakistan. There is, however, not one single mother tongue spoken by Gilgit inhabitants, but many: apart from Shina, there are Burushaski, Pashto and others, as well as Urdu as a lingua franca for educational, professional and administrational purposes. Most people adhere to the religion of Islam, but each of the three groups (Shia, Sunni, and Ismaili) has their own traditions and places of worship, and definitions vary as to which fellow Muslim groups are truly Muslim or are rather to be regarded as apostates or infidels. Religious tension between Shia and Sunni Muslims in Gilgit has often led to severe clashes between the communities, causing several deaths. As to the status of Gilgit as a part of Pakistan, when in 1947 the Maharaja of Kashmir decided to join the Indian Union, a revolt broke out in Gilgit to support Pakistan. Gilgit came under Pakistani administration as part of the Northern Areas. However, the Northern Areas never gained provincial status.

distinction between what is one's own and what is foreign (cf. numerous corresponding proverbs in Degener 2008). Even a cursory glance at this list shows that some of these concepts are incompatible. For a discussion of the conceptualization of conflict in Muslim Arab cultures, cf. Weinman et al. in Oetzel/Ting-Toomey 2006, 551-555.

29 For identities and the social situation in Gilgit in the '80s and '90s see Sökefeld 1997.

30 qaum is translated as ‘quasi-family group’ by M Sökefeld 1997 where various "identities" in Gilgit are treated exhaustively. 
Even today, after the latest efforts on part of the Pakistani cabinet to grant the region full internal autonomy and re-naming it "GilgitBaltistan", the inhabitants of Gilgit are far from being equal to the rights accorded to the citizens of Pakistan. This has resulted in an increasing alienation, ${ }^{31}$ so that declarations of loyalty to the state of Pakistan have sometimes to be taken as wishful thinking rather than expressions of a common feeling. In fact, instead of being a "meltingpot" for people from various backgrounds, Gilgit society at the time of broadcasting Bayáak was characterised by disunity, segregation, religious tension, and political insecurity.

The message of the radio features, markedly promulgated in every single programme, is to build up common interests, to work jointly for the common good. This is in accordance with Muslim ideals and would therefore be readily accepted. Furthermore, as the protagonists are representatives of typical social strata, they invite the listener to adopt their attitudes as his own, which he himself would probably not have been able to formulate in private conversation, and much less in public. It is this virtual participation of the radio listeners which gives Bayáak a significance beyond that of a programme to promote a regional language. It gives people an incentive to think their positions over, and in the process redefine their own identity as members of the community. In this way, the programme, while staging conflicts and their solution, contributes to the transformation of individual and social outlooks. Its aim is in fact much more than entertainment: it is nothing less than the creation of a shared identity for the (Shinaspeaking) citizens of Gilgit. The dialogues of the radio feature act as a model for the establishment of an ideal quasi-democratic community constituted through public participation and dialogue. ${ }^{32}$ If, to judge

31 Sökefeld 1997.

32 J. K. Barge (in Oetzel/Ting-Toomey 2006, 517f.) points out that "the practice of dialogue within communities has at least two important consequences. First, it helps people build community by having them collaboratively work through conflict. ...Second, dialogue fosters democratic practice within communities....Dialogue, with its focus on including all the voices of the public within the conversation and its emphasis on the free, open expression and discussion of different points of view, is crucial for citizens to participate fully in the political decision-making process.” 
from recent developments, this has not proved successful, it does not devalue the high ambitions of the programme.

Staging conflicts between old and young, between tradition and modernity, in fictional conversations, the radio features fulfilled the task to put the finger on some of the actual problems in an entertaining way, to give a public voice to existing disharmonies, to intensify and strengthen the arguments of the opponent parties, to encourage participation in public affairs, and eventually to create solidarity amongst the Shina-speaking population and push social development. In this way the radio features played a very important role in the community life of Gilgit in the '80s, and are evidence for the dynamics of a transforming society in South Asia. ${ }^{33}$

33 More recently Kohistani/Schmidt (2006, 153) evaluate the impact of radio broadcasts in Shina as follows: "Radio programming does have an impact in the listening audience, as it introduces new ideas, international news, national and local political coverage, information about the economy, religious ideas, and so on. To properly assess the impact, a listener survey would be necessary, which was beyond the resources of the authors." 
Appendix: Interlinear version of quoted text passages ${ }^{34}$

Dialogue 1

1. Traypha

nu jéek galát mórak thigás, laá Táaj̆, mas?

this/m what wrong word-m.sg.INDF make-PRT-1sg.m, Part Taaj, IERG

țar bíli barușóyak thoóiky ginií tu judá róos bigáa náa? isolated become-PRT-3sg.f. duck-f.sg.INDF make-INF take-CP you particular anger become-PRT-2sg.m Part

2. Taaǰ

na yá tranpháa, róos boóikyei mor nuš,

NEG Part Tranpha, anger become-INF.GEN word be-not

née róoṣ beé ga mas jéek thoóiky bámus tuṭ?

Part anger become-CP too I-ERG what make-INF become-PRS1 sg.m you-DAT?

atáto saá rpuk hanó, "náwaary-ráwaary tham" thigás toó, thei aní tótoo ek șa wét tak hanús

such-m.sg horse-shoe-m.sg.INDF be-PRS-2sg.m, here-there makeFUT-1sg make-PRT-1sg.m conj, your this-pl paw-m.pl.GEN one blow-sg.DAT enough be-PRS-1sg.m

34 Abbreviations: $\mathrm{ABL}=$ ablative, $\mathrm{CAUS}=$ causative, conj $=$ conjunction, $\mathrm{CP}=$ conjunctive participle, $\mathrm{DAT}=$ dative, $\mathrm{ECHO}=$ echo word, $\mathrm{ERG}=$ ergative, $\mathrm{f} .=$ feminine, FUT = future, GEN = genitive, IAPTC = imperfective adverbial, IMP $=$ imperative, $\mathrm{INDF}=$ indefinitive, $\mathrm{INF}=$ infinitive, $\mathrm{LOCi}=$ locative $\mathrm{i}, \mathrm{LOCii}=$ locative $\mathrm{ii}, \mathrm{m} .=$ masculine, $\mathrm{NEG}=$ negative, nom $=$ nominal element of $\mathrm{a}$ nominal verb, $\mathrm{OBL}=$ oblique, $\mathrm{OPT}=$ optative, Part $=$ particle, $\mathrm{pl}=$ plural, $\mathrm{PPTC}=$ perfect participle, $\mathrm{PRS}=$ present, $\mathrm{PRT}=$ preterite, $\mathrm{Q}=$ interrogative, $\mathrm{sg}$ $=$ singular. 
ek to phat tharoóiky ga koó nuš.

one Part leave-nom + make-CAUS-INF too who be-not.

tu jée Gulam Díin hanó to, jéek reégas to ga "waá mei šutúko, adée neé ra née!" theé čup thée.

you Part Gulam Din be-PRS-2sg.m conj, what say-PRT-1sg.m conj. too Part my bud, so not say-IMP-sg Part make-CP dumb make-FUT$2 \mathrm{sg}$

\section{Traypha}

ye phat the, laá záa! tus to Gulám Díinè açhíi șeéguno.

Part leave-nom + do-IMP-sg, Part brother. you-ERG Part Gulam Din-LOCi eye attach-PERF-2sg.m

má-saa ty beéto to, miștuk beé asíl auláadakei, zaáakei širií beyii mor the!

I-OBL with sit-PRT-2sg.m conj, good-m.sg.INDF become-CP wellbehaved offspring-f.sg.INDF.GEN, brother-m.sg.INDF.GEN like sitCP word do-IMP-sg

aaxír ma tranphá hanús. ma jéek Gulám Díin neé toó thei isiháa moórye timaníi tham.

finally I tranpha be-PRS-1sg.m. I what Gulam Din NEG conj yoursg. mockery word-m.pl tolerate-nom + do-FUT-1sg

4. Taă̌

heyíi hei! ye insáan boóiky heesiyát ginií ga jagó majaá ga kačáak phárak haiñ çaké-t!

Part Part man become-INF status take-CP too people-pl.OBL between too how-much difference be-PRS-sg.f look-IMP-sg-Part 
Dialogue 2

1. Taa ǰ

thei ne to hotaléi júuli ga julaabíye khoóikyei achúunuk haiñ áa i, moórye thoóiky áa i toó mei Gulám Díin zawéi haiñ.

your-sg. this-f.sg Part hotel-sg.GEN sauce and biscuit-pl eatINF.GEN hole-m.sg.INDF be-PRS-sg.f. mouth-f.sg, word-m.pl doINF mouth Part my Gulam Din brother/m.sg.GEN be-PRS-sg.f

\section{Traypha}

ek anú baál Gulám Díin ginií neé beéto

one this-m.sg child Gulam Din take-CP NEG sit-PRT-2sg.m

aaxír ma jéek kam mušáak nuš.

finally I what little man-m.sg.INDF be-not

rajoó maraká bóot yáa kuléi, sarkaarí afsaró muçhoó, adaalató majaá mukh nikháto mušáa anú han, anú tranphá.

king-m.pl.GEN meeting become-OPT or people-sg.GEN, ofgovernment official-m.pl.OBL before, court-pl.OBL between face emerge-PRT-3sg.m man this-m.sg be-PRS-3sg., this-m.sg traypha

mor páčen toó har dišér anú mušáai.

word ripen-PRS-3sg.m conj every place-f.sg.LOCii this-m.sg manm.sg.GEN

mukh loólyo han toó, har dišér anú mušáai. parúdoo?

face red be-PRS-3sg conj, every place-f.sg.LOCii this-m.sg manm.sg.GEN. hear-PRT-2sg.m 
Dialogue 3

1. Taау

har dišér oó manúzei mór-se diš laámen tonée eései kom nikháan, koós munaafiqát thoóiky suí yen, lik doóiky tíyen, jaaíz ga naajaaíz tariká ginií toóm hațáal kom nikhaloóikyet áar das neé théen.

every place-f.sg.LOCii that-m.sg man-m.sg.GEN word-ERG place catch-PRS-3sg.m and-also that-m.sg.GEN work emerge-PRS-3sg.m, who-ERG hypocrisy do-INF know-PRS-3sg.m, bribe give-INF canPRS-3sg.m, legal and illegal way take-CP own blocked work bringout-INF.DAT shame know-nom NEG do-PRS-3sg.m

2. Traypha

heee , mor kóto thigáa.

Part, word recent do-PRT-2sg.m.

Gulám Díinei moóryes diš lamoóiky çaké, rései lik doóiky paáš!

Gulam Din-sg.GEN word-m.pl.ERG place catch-INF look-IMP-sg, that-sg.GEN bribe give-INF see-IMP-sg

toóm mataláb nikhaloóikyet jagoóo máal-háal húuși doóikyei kom toó Gulám Dín-se mísțtuk theé dišét waléen.

own object bring-out-INF-DAT people-pl.GEN possession-state loot give-INF.GEN work Part Gulam Din-ERG good-m.sg.INDF do-CP place-f.sg.DAT bring-PRS-3sg.m

ros akíi ráan ki "bes jagóojo karkaámuše ga hanejé sinaleé traך oó še-apháarot dóoneses tonée tray toóm gotét hároneses" theé.

that-sg.ERG self say-PRS-3sg.m conj we-ERG people-pl.ABL hen-pl and egg-f.pl collect-CP half guest-m.pl-guest-pl.DAT give-IMPF-1pl and-also half own house-m.sg.DAT take-IMPF-1pl. do-CP 
3. Taă

ma tayáar nuš thei mor manoóiky; ma gáahi tayáar nuš Gulám Díinei xaláaf ek mor parujoóiky.

I ready be-not your-sg. word accept-INF; I once ready be-not Gulam Din-sg.GEN contrary one word hear-INF

4. Traypha

téen guču-gučeél páaye neé șe neé!

now in-vain foot-m.sg NEG attach-IMP NEG

uçií bayáaker toó ma ga Gulám Díin bé ye toóm isiháa moórye ginií naaphalák theé aš ro tus kačáak sumúluk páašano?

before-yesterday meeting-place-sg.LOCii Part I and Gulam Din both own ridicule word-m.pl take-CP abuse-nom + do-CP today that youERG how-much holy-m.sg.INDF see-PRS-2sg.m

5. Taă

waá trappháa

Part Trangpha

mor koó ga béen náa, oó mukhá thoóiky yupóoš béen.

word who too become-PRS-3sg Part, that face-to-face do-INF appropriate become-PRS-3sg.m

aš Gulám Díin ga maaștár sáap nuš theé rinéi píte phatú rinót čóde deégyes to, anú mor místuk béy-aa?

today Gulam Din and Mashtar Saap be-not do-CP that-pl.GEN backm.sg.OBL behind that-pl.DAT abuse-m.pl give-PRT-1pl conj, thism.sg word good-m.sg.INDF become-FUT-3sg-Q 
Dialogue 4

1. Traypha

ye çaké née! ḍaalḍáai jawáanoo máto!

Part look-IMP-sg Part! Daaldaa-sg.GEN youth-m.pl.GEN brain

jáale-jo çíto giíyak laṣ neé thíte čáakuroo pháam akii kam haiñ ya!

be-born-PPTC-m.sg.ABL bitter ghee-sg.INDF lick-nom NEG doPPTC-m.pl lad-m.pl.GEN intelligence self little be-PRS-sg.f. Part

2. Taă̌

awá, cho çíto giyéi lagáare jak bóde bạre sawéene yáani Aflatúuni ga Sakaráati hanet hoó.

Part you-pl bitter ghee-sg.GEN adherent-m.pl people much-m.pl bigm.pl wise-m.pl namely Plato-pl and Socrates-pl be-PRS-2pl Part

gií ga pajúu kámak baáski kháa to, ho blaḍ-préšer beé lanijoóiky hanét.

ghee and salt little-INDF more-f eat-IMP-pl conj then blood-pressure become-CP die-INF be-PRS-2pl

Dialogue 5

1. Taa j

ye bas, "xuškhatíi kúri thámus" theé, née Gulám Díinei mor wáan, "mukhéj dul-khalúc ginií xuškhatíi bósak theé laár be hótal hótal júulyer pajúu çakóoja yaáyeno."

Part enough, calligraphy hard-sg.f. do-PRS-1sg.m do-CP, Part Gulam Din-GEN-sg. word come-PRS-3sg.m, face-LOCi-sg.m. collyriummake-up take-CP calligraphy plenty-INDF do-CP swaggering become-CP hotel hotel sauce-LOCii-sg.f. salt look-IAPTC go-PRS2sg.m 
2. Traypha

Táaǰ, tut aaxír aséi bazáarer kiirr-kaár boóiky ga kye kháči dî̉in?

Taaj, you-sg.DAT finally our bazaar-LOCii-sg. stroll-nom + become-INF too why bad-sg.f. fall-PRS-3sg.f.

maphéeri jée bathunáryeǰ tráa theé ganeé çho čáakur-násal-se maroóiky guneégyenet bei?

old-man-pl. Part hearth-stone-LOCi-sg. beat-nom + do-CP bind-CP you-pl. lad generation-ERG-sg. kill-INF think-PERF-2pl. becomeFUT-3sg.

3. Taaǰ

aséi baábei jéek toofíiq haiñ cho ganoóiky?

our father-GEN-sg.m what power-sg.f. be-PRS-sg.f. you bind-INF

bes chho ganeégyes to, šukáai brakér karkaámušek nasáalei bagóok yáa mútu jéek číizek deé bári kháan jagoót lik doóiky koó bújen?

we-ERG you bind-PRT-1pl. conj, cloak-GEN-sg. fold-LOCii-sg.f. chicken-INDF Nasaalo(feast)-GEN-sg. portion-INDF or other-sg.m. what thing-sg.f.-INDF give-CP bribe eat-FUT-3pl. people-DAT-pl. bribe give-INF who go-FUT-3pl.

ro, mor-se mor nikhalaréen.

that word-ERG word bring-out-CAUS-PRS-3sg.m

čága neé tham thigásus, téen thoóiky akíi áali.

story NEG do-FUT-1sg. do-PLUP-1sg.m, now do-INF self comePRT-3sg.f.

Gulám Díin lambardáar-se aš toóm brakér karkaámušek deé toóm hatáal kómak nikhaloóikyet gou. 
Gulam Din lambardaar-ERG-sg. today own fold-LOCii-sg chickenINDF give-CP own blocked work-INDF bring-out-INF-DAT-sg. goPRT-3sg.m

parúčl chos adée tháanet.

hear-IMP-sg. you-pl.ERG so do-PRS-2pl.

4. Traypha

ye behél bo! pašiiga be čal zamaanáai mukh nikháte jagóo mísțti aadát?

Part bravo become-IMP-sg. see-PRT-2sg.m we former epoch-GENsg. face emerge-PRT-3pl. people-GEN-pl. good-sg.f. habit

bes toóm yáar-báar ga daftaróo sijón-pašón jagoót daróm daalíyek thoóikyei kom neé nayeégyenes.

we-ERG own friend-ECHO and office-GEN-pl.f. known-seen people-DAT-pl. still present-INDF do-INF-GEN-sg.f. work NEG lose-PERF-1 pl.

5. Taă

daalí jéekei? lik doóiky the, lik doóiky!

present what-Gen? bribe give-INF do-IMP-sg., bribe give-INF!

Dialogue 6

1. Taă

yáani juúk ga núšej trapphás dozakhéi hagáaret prik digáa. namely contact too be-not-LOCi tranpha-ERG-sg. hell-GEN-sg.f. fire-DAT-sg.m. jump-nom + give-PRT-2sg.m 
2. Traypha

re kye laá záa?

that-sg.f. why Part brother

éket toóm kom garasyaroóikyet jéekek digáa to, kháči thigáa née?

one-DAT own work achieve-INF-DAT-sg. what-INDF give-PRT2sg.m conj bad-sg.f. do-PRT-2sg.m Part

ané dozakhéi hagáarei čága neé tháa ya!

this-sg.f. hell-GEN-sg.f. fire-GEN-sg.m. story NEG do-IMP-2pl. Part

ma kúri arr bámus.

I hard-sg.f. terror become-PRS-1sg.

\section{Maaștar Saap}

traypháa, Táaǰ-se súu ço ráan.

Traypha, Taaj-ERG right-sg.m. say-PRS-3sg.m

nus to ek hadíis šariifekei hawaalá deé tuṭ híjĭi tharéen, keése majaá rayítin

this-ERG-sg.m. Part one hadith noble-INDF-GEN-sg.m. quote-nom + give-CP you-DAT memory do-CAUS-PRS-3sg.m, who-OBL-sg. in say-PPTC-3sg.f. + PRS-3sg.f

“ar-raašii waalmurtašii finnaari jahannum” yáani lik déyak ga bári kháayak bé ye dozakhéi máal han.

(ar-raašii waalmurtašii finnaari jahannum) namely bribe give-FUT3sg.-INDF and bribe eat-FUT-3sg.-INDF both hell-GEN-sg.f. property-sg.m. be-PRS-pl.m 
4. Traypha

bei mor, bei mor han.

become-FUT-3sg. word, become-FUT-3sg. word be-PRS-3sg.m

lekín dozakhét bujoóikye káary toó bósak bári khoóiky zarurí neé béy-aa?

but hell-DAT-sg.f. go-INF-OBL-sg. because Part plenty-INDF bribe eat-INF-sg.f. necessary NEG become-FUT-3sg.-Q

Dialogue 7

1. Taă̌

aáiñ "šóo šóo" theé gyeé née toóm dišér danii toómi akíi dée. here fine-sg.m. fine do-CP go-CP Part own place-LOCii-sg.f. giving own-sg.f. self give-FUT-2sg.

urinéi širií dáar maraák beé amušoóiky toó thei aadát haiñ. mountain-sheep-GEN-sg.f. like mountain turn become-CP forget-INF Part your-sg. habit-sg.f. be-PRS-3sg.f.

2. Traypha

neé ya, Táaj! ma aaxér próono mušáa hanús.

NEG NEG, Taaj. I finally old-sg.m. man be-PRS-1sg.m

rajú wazíiri ga sarkaarí afsáro sáa ty khíto píto insáanak hanús. king-pl.m. wazir-pl.m. and of-government official-OBL-pl. togetherwith eat-PPTC-sg.m drink-PPTC-sg.m man-INDF be-PRS-1sg.m

aaxér ayáakak saadá tus ma ga neé kalí née!

finally such-INDF simple you-sg.ERG I too NEG count-IMP-2sg. Part 
Dialogue 8

1. Traypha

aní aš-balá zamaanáai ayaašiíyo phatú gárak čáakak šudáaryes téen hamarí ga toonóo deé gúum makéi bazáarer lam thareégye-t, khyée theé bes híiyo šóo thóon, laá máaștar sáap, ninójo?

this-pl today-yesterday epoch-sg.GEN luxuriousness-pl.OBL behind immersed some child-pl.ERG now corn-container and wheatcontainer-pl.GEN beat-CP wheat maize bazaar-sg.LOCii take-awaynom + do-CAUS.PRT-3pl conj how-f. do-CP we-ERG heart-m.sg fine-m.sg do-FUT-1pl, Part Maashtar Saap, that-pl.ABL

2. Taај

awá náa, toóm hotaléi našá phatuú thoóikyet toó tus jéek ga neé théeno?

yes Part, own hotel-sg.GEN intoxication achieve-nom + doINF.DAT Part you-sg.ERG what too NEG do-PRS-2sg.m

tom-talúu, šúko meewá ga laç-čhaál çhos hotáléi šáawo mazá uḍoór thóoja çhawáa tonée asót kanaáo tháa to bes kon deé beétes?

tree-shrub, dry-m.sg fruit and goat-kid you-pl.ERG hotel-sg.GEN vegetable-pl.GEN taste seek-nom + do-IAPTC waste-IMP-pl andalso we-DAT advice do-IMP-pl.conj we-ERG ear give-CP sit-PRT$1 \mathrm{pl}$ 
References

Billig, Michael:

1989 The argumentative nature of holding strong views: A case study. In: European Journal of Social Psychology, 19, 3, 203223.

Buddruss, Georg:

1983 Neue Schriftsprachen im Norden Pakistans. Einige Beobachtungen. In: A. and J. Assmann/ Chr. Hardmeier (ed.): Schrift und Gedächtnis. Archäologie der literarischen Kommunikation. München, pp. 231-244.

1993a Shina. Muhammad Amin Zia: An meine Lebensgefährtin. In: Sontheimer, Günther-Dietz (ed.), Südasien-Anthologie. 44 Übersetzungen aus südasiatischen Literaturen, published by the Südasien-Institut, Universität Heidelberg. Beiträge zur Südasienforschung, 140. Stuttgart, pp. 1-4.

1993b German linguistic research in the Northern Areas of Pakistan. In: Neuere deutsche Beiträge zu Geschichte und Kultur Pakistans (Schriftenreihe des Deutsch-Pakistanischen Forums, 10), 38-49.

Degener, Almuth

2008 Shina-Texte aus Gilgit (Nord-Pakistan). Sprichwörter und Materialien zum Volksglauben, gesammelt von Mohammad Amin Zia. (Beiträge zur Indologie, ed. by Konrad Meisig, 41). Wiesbaden.

Grein, Marion and Weigand, Edda, eds.:

2007 Dialogue and Culture. (Dialogue Studies, 1). Amsterdam/ Philadelphia 2007.

Grimshaw, Allen D., ed.:

1990 Conflict Talk. Sociolinguistic Investigations of Arguments in Conversations. Cambridge. 
Hartung, Martin:

1998 Ironie in der Alltagssprache: eine gesprächsanalytische Untersuchung. Opladen.

Holzwarth, Wolfgang:

1998 Change in pre-colonial times: An evaluation of sources on the Karakorum and Eastern Hindukush Regions (from 1500 to 1800). In: Karakorum - Hindukush - Himalaya: Dynamics of Change, ed. by Irmtraud Stellrecht, Part II, 297-336.

2008 Der persische Feenprinz besiegt den Kannibalenkönig von Gilgit: Ein Kapitel aus der Kulturgeschichte Nordpakistans. Beiträge zur Iranistik, 27: Iran und iranisch geprägte Kulturen. Festschrift Bert G. Fragner, hrsg. von M. Ritter, R. Kauz, B. Hoffmann. Wiesbaden.

Johnstone, Barbara:

1989 Linguistic strategies and cultural styles for persuasive discourse. In: Language, Communication, and Culture: Current Directions. (International and Intercultural Communication Annual XIII), ed. by Stella Ting-Toomey and Felipe Korzenny. Beverly Hills: Sage, 1989, 139-156.

Kakavá, Christina:

2001 Discourse and conflict. In: The Handbook of Discourse Analysis, ed. by D. Schiffrin, D. Tannen and H. E. Hamilton, 2001, 650-670.

Kohistani, Razwal and Schmidt, Ruth Laila:

2006 Shina in contemporary Pakistan. In: Lesser-Known Languages of South Asia, ed. by A. Saxena and L. Borin. (Trends in Linguistics. Studies and Monographs, 175.). Berlin/ New York, 137-160.

Leung, Santoi:

2002 Conflict talk. A discourse analytical perspective. In: Teachers College, Columbia University Working Papers in TESOL \& Applied Linguistics, Vol. 1, 3, 1-19. 
Oetzel, John G. and Ting-Toomey, Stella, eds.:

2006 The Sage Handbook of Conflict Communication. Integrating Theory, Research, and Practice. London/New Delhi.

Sökefeld, Martin:

1997 Ein Labyrinth von Identitäten in Nordpakistan. Zwischen Landbesitz, Religion und Kaschmir-Konflikt. (Culture Area Karakorum Scientific Studies, 8). Köln.

Weigand, Edda, ed.:

2004 Emotion in dialogic interaction, ed. by Edda Weigand (Amsterdam Studies in the Theory and History of Linguistic Science. IV, Current Issues in Linguistic Theory, vol. 248), 2004, 265-276. 